\title{
STUDI JUMLAH TROMBOSIT ANTARA PENDONOR LAKI-LAKI DAN PEREMPUAN PADA USIA YANG BERBEDA DI UNIT TRANSFUSI DARAH CABANG KOTA MALANG
}

\author{
Anis Nur Khasanah ${ }^{1}$, Suyadi ${ }^{2}$ \\ ${ }^{1,2)}$ Jurusan Biologi Universitas Islam Negeri Malang \\ anisha.ridwan@yahoo.com
}

\begin{abstract}
Blood is part of the body which has 6-8 \% of total body weight which include of the blood cell and plasma. Thrombocyte is one of component in the blood which has an important function in blood coagulation. This study is aimed to evaluate the influence of the sex and age of donor on the number of thrombocyte. Blood sample were collected at Blood Transfusion Unit of Malang. This research using cases study whose use to observe the number of thrombocyte in man and woman donor at different age. Total of 40 sample (20 of each sex) whose classified as $\mathbf{3 1}$, 31-40, 41-50 and 251 years of age. The number of thrombocyte which determined by hemocytometer and observe under microscope (magnification: 100 ). The collected data where analyze by unpaired T-test for man and woman one. While Anova whose use to analyze the differences between ages interval both in the man and woman. Duncan test (5\%) whose use to determine the significant different between ages group. The result show that the number of thrombocyte whose significantly higher $(P<0,05)$ than those in the woman $(245.750 \pm 76300$ vs $201.750 \pm 61564)$. The age of donor whose significantly influence on the number of thrombocyte $(P<0,05)$ both in the man and woman. The number of thrombocyte degrees significantly by increasing the age. However for the both sex can donor the blood of more than 51 years of age.
\end{abstract}

Keywords: thrombocyte, man, woman and age.

\section{PENDAHULUAN}

Unit Transfusi Darah (UTD) bertujuan untuk memenuhi kebutuhan darah bagi penderita untuk menyelamatkan jiwanya, sehingga perlu dilakukan dengan indikasi yang jelas dan tepat. Tujuan utama transfusi darah adalah untuk mempertahankan jaringan penderita agar tetap mendapatkan oksigen yang optimal (Rustam, 1978). Upaya kesehatan transfusi darah adalah upaya kesehatan berupa segala tindakan yang dilakukan dengan tujuan untuk memungkinkan penggunaan darah bagi keperluan pengobatan dan pemulihan kesehatan (Rudy, 2007).

Darah merupakan bagian tubuh yang jumlahnya 6-8 \% dari berat badan total, yang terdiri atas 45-60 \% sel-sel darah terutama eritrosit dan 40-55 \% plasma (Marieb, 2005). Fungsi utama darah adalah sebagai media transportasi, memelihara suhu dan memelihara asam dan basa cairan tubuh (Kosasih, 1983).

Trombosit (platelet) adalah salah satu komponen darah yang berupa fragmen sitoplasma megakariosit yang tidak berinti, dengan ukuran yang lebih kecil dari sel darah merah atau sel darah putih. Trombosit berfungsi sebagai bagian dari mekanisme perlindungan darah untuk menghentikan perdarahan. Ketika terjadi luka maka trombosit berkumpul pada daerah yang mengalami perdarahan dan mengalami pengaktifan.

Setelah mengalami pengaktifan, trombosit akan melekat satu sama lain dengan cara menggumpal untuk membentuk sumbatan yang membantu menutup pembuluh darah dan menghentikan perdarahan. Pada saat yang sama, trombosit melepaskan bahan yang membantu mempermudah pembekuan (Ganong, 1983). Bahan yang membantu 
proses pembekuan darah tersebut adalah faktor trombosit 1-13 dan hanya ada 3 faktor yang khusus untuk kerja trombosit yaitu faktor 2, 3, dan 4 (Marieb, 2005). Trombosit merupakan suatu komponen darah yang sulit diperoleh daripada komponen darah lainnya sebagaimana plasma dan eritrosit. Hal itu terjadi karena konsentrasinya di dalam darah relatif kecil dan alat feresis yang diperlukan untuk melakukan donor khusus trombosit masih jarang dimiliki oleh UTD sehingga ketersediaannya menjadi langka.

Beberapa kasus ditemukan adanya pengaruh usia jika dikaitkan dengan metabolisme dalam tubuh termasuk volume darah. Menurut Guyton (1989), pada masa pubertas sampai dewasa kemampuan metabolisme dalam tubuh meningkat. Volume darah dapat dibedakan berdasarkan usia seseorang, sehingga dengan perbedaan usia maka volume darah akan berbeda pula. Manusia untuk memenuhi kebutuhan hidupnya melakukan proses metabolisme di dalam tubuhnya.

Menurut Linder (1992), banyaknya variasi komponen biokimia ditambah dengan variasi susunan anatomis dan fisiologis pada pria dan wanita mempunyai implikasi berbeda dalam beberapa hal. Secara khusus dapat diterangkan bahwa suatu keadaan tidak akan memberikan hasil yang sama untuk setiap individu, terlebih bagi mereka yang berjenis kelamin berbeda dan laju metabolisme pada wanita diketahui sedikit lebih rendah daripada pria pada segala usia (Ganong, 1983). Sehingga dengan perbedaan usia dan jenis kelamin maka volume darah akan berbeda pula termasuk volume eritrosit, trombosit, dan plasma darah. Salah satu cara yang dapat dilakukan untuk mengetahui perbedaan tersebut adalah perlu dilakukan penelitian tentang jumlah trombosit antara pendonor laki-laki dan perempuan pada usia yang berbeda melalui Unit Transfusi Darah Cabang (UTDC) kota Malang.

\section{METODE}

$\begin{array}{llr}\text { Penelitian } & \text { ini dilakukan di } \\ \text { Laboratorium } & \text { Biologi Molekuler }\end{array}$ Universitas Islam Negeri (UIN) Malang. Penelitian ini merupakan penelitian studi kasus dengan melakukan penghitungan jumlah trombosit pendonor di UTDC kota Malang dengan tidak mengaitkan antara jenis kelamin, karena masingmasing jenis kelamin akan diamati secara terpisah. Jenis kelamin laki-laki dan perempuan dibekan dengan menggunakan Uji $t$ tidak berpasangan, pengaruh usia dengan jenis kelamin laki-laki atau perempuan digunakan Anova one-way. Jenis kelamin dikelompokkan berdasarkan usia yaitu $\leq 30$ tahun, 31-40 tahun, 4150 tahun, dan $\geq 51$ tahun, masing-masing kelompok dengan 5 kali ulangan.

Populasi dari penelitian ini adalah trombosit pada hemacytometer yang akan diamati di bawah mikroskop dengan perbesaran 100 dan 400x, sampel yang diambil terdapat pada 5 lapang pandang $\mathrm{R}$ (digunakan juga dalam mengamati eritrosit).

Alat yang akan digunakan dalam penelitian ini adalah termos es, termometer suhu, botol antisera, hemocytometer type double improve neubauer, kaca penutup, cawan petri, pipet thoma/penghisap eritrosit, pipet pembersih, mikroskop binokuler mikrokomputer, alat penunjuk waktu/jam, cutter, gelas beker, handscoon, counter, kapas, dan tissue. Bahan yang diperlukan adalah larutan Rees-Ecker (yang terdiri atas campuran sodium sitrat 38gr, brilliant cresyl blue 1 gr, formalin $40 \%$, aquades $1000 \mathrm{ml}$ ), es, alkohol, aquades, dan darah dengan antikoagulan Citrate Phosphate Dextrosa Adenine (CPDA) yang diambil dari pendonor di UTDC kota Malang.

\section{HASIL DAN PEMBAHASAN}

Hasil perhitungan jumlah trombosit per $\mathrm{mm}^{3}$ pada pendonor laki-laki dan perempuan di UTDC kota Malang disajikan dalam tabel 1. Hasil tersebut menunjukkan bahwa jumlah trombosit antara pendonor 
laki- laki dan perempuan di Unit Transfusi Darah Cabang (UTDC) kota Malang pada kisaran usia yang berbeda adalah dalam keadaan normal. Jumlah trombosit seperti ini dikatakan dalam taraf normal sebab menurut Eastham and Slade (1992), jumlah trombosit normal pada orang dewasa berkisar antara 150-400×10\%/l, sedangkan menurut Kresno (1988), berkisar antara $150.000-450.000 \mathrm{~mm}^{3}$ dan Guyton (1989), konsentrasi normal trombosit dalam darah adalah 200.000$400.000 / \mathrm{mm}^{3}$.

Tabel 1. Hasil penghitungan jumlah trombosit per $\mathrm{mm}^{3}$

\begin{tabular}{ccc}
\hline Usia & $\begin{array}{c}\text { Laki-laki } \\
(x \pm \text { SD })\end{array}$ & $\begin{array}{c}\text { Perempuan } \\
(x \pm \text { SD })\end{array}$ \\
\hline$\leq 30$ & $296.000 \pm 71.972$ & $249.000 \pm 34.168$ \\
$31-40$ & $285.000 \pm 86.962$ & $231.000 \pm 65.802$ \\
$41-50$ & $227.000 \pm 51.063$ & $165.000 \pm 64.226$ \\
$\geq 51$ & $175.000 \pm 22.912$ & $162.000 \pm 29.283$ \\
\hline
\end{tabular}

Meskipun laki-laki dan perempuan dari segi pertumbuhannya relatif sama, tapi ada beberapa hal yang membuat mereka berbeda dalam hal perkembangan. Linder (1992), menjelaskan bahwa banyaknya variasi komponen biokimia (hormon), anatomi dan fisiologi (pertumbuhan, perkembangan, organ) pada laki- laki dan perempuan mempunyai implikasi yang berbeda dalam beberapa hal, termasuk didalamnya dalam hal produksi sel darah. Salah satu bentuk dari sel darah adalah trombosit. Sedangkan pertumbuhan umumnya bersifat kuantitatif sehingga nilainya dapat dinominalkan, sebaliknya perkembangan sifatnya adalah kuantitatif sehingga nilainya tidak dapat dinominalkan, akan tetapi pertumbuhan dan perkembangan tidak dapat dipisahkan seperti halnya tulang dalam memproduksi trombosit.

Hormon pertumbuhan manusia (HGH) adalah hormon yang bertanggung jawabuntuk mengatur pertumbuhan pada diri seseorang. Selain untuk pertumbuhan, produksi $\mathrm{HGH}$ sangat mempengaruhi produksi hormon lainnya di dalam tubuh manusia. Sedangkan pada fase pertumbuhan diketahui ada sedikit perbedaan antara berat dan tinggi badan anak laki-laki dan perempuan sampai mencapai masa puber, anak perempuan lebih besar daripada anak laki-laki. Akan tetapi pada saat puber, tinggi badan anak perempuan mulai stabil, sedangkan anak laki-laki masih terus mengalami pertumbuhan. Sehingga proporsi tulang pada laki-laki lebih besar daripada pada perempuan. Diketahui pula bahwasannya pertumbuhan tulang selain dipengaruhi oleh hormon pertumbuhan yakni hormon pertumbuhan manusia (HGH) juga dipengaruhi pula oleh aktivitas seseorang.

Trombosit yang diproduksi dari sumsum tulang tepatnya diturunkan dari sitoplasma megakariosit yaitu merupakan sel terbesar di dalam sumsum tulang dengan inti polimorf yang saling berhubungan akan diproduksi dalam jumlah yang lebih besar jika tulang dan megakariosit dalam keadaan normal. Tulang dikatakan normal apabila tidak mengalami kerusakan dan megakariosit dikatakan normal jika mampu berdifferensiasi dengan baik. Keadaan seperti ini akan mendukung metabolisme di dalam tulang dan juga megakariosit. Semakin besar tulang maka megakariosit di dalamnya akan memiliki ukuran yang maksimal dan megakariosit yang besar akan memiliki massa sitoplasma yang lebih besar pula. Linder (1992), menjelaskan bahwa rata-rata laki- laki memiliki proporsi tulang yang lebih besar dibandingkan dengan perempuan sehingga tidak heran jika metabolisme pada lakilaki juga lebih besar daripada metabolisme pada perempuan. Jika dalam suatu metabolisme, energi yang diperoleh untuk menjalankan sintesis didapatkan dalam jumlah yang besar maka energi yang digunakan untuk mensintesis trombosit pun juga semakin besar karena dalam menjalankan suatu sintesis, energi diperlukan dalam jumlah yang sangat besar. Sehingga dengan semakin besarnya proporsi tulang pada laki-laki, maka akan diproduksi 
trombosit dalam jumlah besar demikian pula dengan proporsi tulang yang yang lebih kecil pada perempuan, maka akan diproduksi trombosit dalam jumlah yang kecil pula.

\section{Pengaruh usia terhadap jumlah trombosit pendonor.}

Usia berpengaruh signifikan terhadap jumlah trombosit pendonor dengan nilai 0,028 pada pendonor lakilaki dan 0,031 pada pendonor perempuan. Hal ini sesuai dengan pendapat Guyton (1989), yang menyatakan bahwa pada masa pubertas sampai dewasa kemampuan metabolisme dalam tubuh meningkat dan metabolisme akan mengalami penurunan seiring dengan bertambahnya usia, sehingga usia mempengaruhi produksi trombosit secara tidak langsung.

Metabolisme berkaitan erat dengan pembentukan dan penguraian zat dan kemampuan metabolisme sering dikaitkan dengan usia seseorang. Semakin bertambah usia seseorang maka kemampuannya dalam pembentukan dan penguraian zat akan berkurang pula. Sebagaimana megakariosit yang terstimulasi oleh faktor pembentukan trombosit (BFU-Mega dan CFU-Mega) maka ia akan berdifferensiasi dan selanjutnya akan menurunkan trombosit. Sel matang menurut Junqueira (1992), adalah sel yang telah berdiferensiasi mencapai tahap dimana sel telah memiliki kemampuan untuk melaksanakan segala fungsi. Sedangkan Rafnar (2001), menjelaskan bahwa dasar pematangan megakariosit adalah setelah membran internal megakariosit kompak. BFU-Mega dan CFU-Mega mestimulasi pembentukan trombosit dengan cara mempercepat perkembangan sistem membran internal megakariosit setelah ini sitoplasma megakariosit akan siap untuk menurunkan trombositnya. Aprianti et al., (2008), semakin bertambah usia seseorang maka kemampuannya dalam melakukan aktivitas juga semakin lemah dan dengan semakin bertambahnya usia seseorang sejumlah hormon akan diproduksi dalam jumlah yang semakin sedikit. Sebagaimana hormon androgen, tiroid, dan hormon pertumbuhan. Hormon androgen sangat berpengaruh terhadap hematopoisis dan hormon tiroid berpengaruh terhadap tingkat metabolisme basal sedangkan hormon pertumbuhan berpengaruh terhadap proses pertumbuhan yang terjadi dalam tubuh individu, yang mana akibat dari hormon pertumbuhan ini sangat mudah dideteksi terutama dari segi fisik seseorang.

Volume darah merupakan keseluruhan komponen darah yang terdapat di dalam tubuh individu. Sadikin (2002), menyatakan bahwa volume darah pada orang dewasa sehat ditentukan oleh jenis kelamin. Volume darah pada laki-laki dewasa adalah 5 liter, sedangkan pada perempuan dewasa agak lebih rendah yaitu 4,5 liter meskipun nilai ini bukanlah nilai mutlak. Diperkirakan untuk setiap individu adalah sekitar 6-8\% dari berat badan total, yang terdiri atas 45 $60 \%$ sel- sel darah terutama eritrosit dan 40-55\% plasma (Marieb, 2005), sedangkan volume leukosit dan trombosit diperkirakan adalah 1-2\% dari volume sel-sel darah (Soewolo, 2005). Berarti pada individu seberat $70 \mathrm{~kg}$ kira-kira memiliki volume darah sekitar 5,6 liter dengan volume trombosit sekitar 0,112 liter saja. Kecilnya konsentrasi trombosit dalam tubuh individu ternyata terdiri dari jumlah yang besar dan mengandung komponen-komponen yang penting sehingga peranannya menjadi mutlak diperlukan oleh tubuh. Berkurangnya jumlah trombosit dibawah ketentuan minimal medis $\left(\triangle 50.000 / \mathrm{mm}^{3}\right)$ akan menyebabkan kesulitan dalam pembekuan darah. Karena dengan berkurangnya jumlah trombosit maka fungsi trombosit dalam tubuh akan menurun. 


\begin{tabular}{ccccccc}
\hline \multirow{2}{*}{ Jenis Kelamin } & Kondisi & \multicolumn{4}{c}{ Kelompok Usia } & Total (\%) \\
\cline { 5 - 6 } & Trombosit/ $\mathrm{mm}^{3}$ & $\leq 30$ & $31-40$ & $41-50$ & $\geq 51$ & \\
\hline Laki-laki & $<150.000$ & 0 & 0 & 0 & 0 & 0 \\
& $>150.000$ & 12,5 & 12,5 & 12,5 & 12,5 & 50 \\
Perempuan & $<150.000$ & 0 & 0 & 2,5 & 0 & 2,5 \\
& $>150.000$ & 12,5 & 12,5 & 10 & 12,5 & 47,5 \\
Total (\%) & & 25 & 25 & 25 & 25 & 100 \\
\hline
\end{tabular}

Tabel 2. Prosentase kondisi trombosit standar

Berdasarkan tabel 2 dapat diketahui bahwa $97,5 \%$ dari pendonor memiliki jumlah trombosit normal. Sedangkan 2,5\% dari 40 orang kondisi trombositnya kurang dari ketentuan medis yaitu $<150.000 / \mathrm{mm}^{3}$ maka ada kemungkinan dari pendonor tersebut akan mengalami kesulitan dalam pembekuan darah jika terjadi trauma vaskuler sebab trombosit berfungsi untuk memelihara supaya pembuluh darah tetap utuh setelah mikrotrauma dan produksinya akan meningkat beberapa kali lipat ketika diperlukan untuk sumbat primer dan stabilisasi fibrin.

Tubuh mampu meningkatkan produksi trombosit hingga 8 kali lipat pada saat dibutuhkan. Ketika pembuluh darah rusak atau terjadi luka, maka trombosit akan menempel pada permukaan endotel yang rusak untuk membentuk sumbat (platelet plug) dengan cara adhesi trombosit. Adhesi trombosit adalah melekatnya trombosit ke permukaan non-trombosit yang akan dibantu oleh von Willebrand Factor (vWF). Setelah adhesi, trombosit mengalami perubahan bentuk dari bentuk disk menjadi bentuk yang lebih sferis dan substansi yang aktif secara biologis seperti ADP, serotonin, $\beta$-TG, PF4, PDGF, TX-A2, dan vWF akan dikeluarkan dari granul trombosit untuk mempercepat pembentukan plug trombosit yang berperan dalam proses perbaikan jaringan. Setelah adhesi trombosit maka terjadilah agregasi trombosit. Agregasi trombosit merupakan perlekatan trombosit dengan trombosit dibantu oleh
ADP, epinefrin, kolagen, trombin, kompleks imun dan faktor yang mengaktifasi trombosit(platelet-activating factor) untuk meningkatkan ukuran plug pada tempat yang luka. Kurangnya jumlah trombosit ini bisa disebabkan karena pengaruh aktivitas atau karena pendonor tersebut mengkonsumsi semacam obatobatan yang dapat menekan produksi trombosit di dalam tubuhnya untuk sementara sebelum melakukan donor, karena jika dilihat dari usianya, secara fisiologis pendonor tersebut masih dalam keadaan baik sebagaimana pendonor lain dalam usia yang setara.

Dua kelompok perlakuan yaitu jenis kelamin laki-laki dan perempuan telah diketahui memiliki pengaruh yang signifikan terhadap jumlah trombosit pendonor di UTDC kota Malang. Pengaruh ini dapat dibedakan berdasarkan tingkat signifikannya masing-masing. Berdasarkan uji percobaan faktorial diketahui bahwa usia pendonor pada jenis kelamin laki- laki berpengaruh lebih nyata/lebih signifikan terhadap jumlah trombosit donor dengan nilai 0,028 dibandingkan dengan pendonor pada jenis kelamin perempuan dengan nilai 0,031 .

Data yang signifikan dilakukan uji lanjut Jarak Duncan. Uji ini dilakukan untuk mengetahui interval usia pada pendonor laki-laki dan perempuan di UTDC kota Malang yang paling signifikan dalam memproduksi trombosit. Hasil uji lanjut Jarak Duncan diketahui bahwa baik pada pendonor laki- laki maupun perempuan seiring dengan 
bertambahnya usia maka jumlah trombositnya akan semakin menurun. Artinya pendonor yang menyumbangkan darahnya maka seiring dengan bertambahnya usia, jumlah trombosit yang terkandung di dalam darahnya akan semakin sedikit.

Tabel 3. Hasil Notasi Uji Jarak Duncan (UJD) usia pada pendonor laki-laki dan perempuan terhadap jumlah trombosit di UTDC kota Malang.

\begin{tabular}{cccccc}
\hline $\begin{array}{c}\text { Usia pendonor } \\
\text { laki-laki (tahun) }\end{array}$ & $\begin{array}{c}\text { Rata-rata jumlah } \\
\text { trombosit } / \mathrm{mm}^{3}\end{array}$ & Notasi & $\begin{array}{c}\text { Usia } \\
\text { Pendonor } \\
\text { Perempuan } \\
\text { (tahun) }\end{array}$ & $\begin{array}{c}\text { Rata-rata jumlah } \\
\text { trombosit } / \mathrm{mm}^{3}\end{array}$ & Notasi \\
\hline$\geq 51$ & $175.000 \pm 22.912$ & $\mathrm{a}$ & $\geq 51$ & $162.000 \pm 29283$ & $\mathrm{a}$ \\
$41-50$ & $227.000 \pm 51.063$ & ab & $41-50$ & $165.000 \pm 64226$ & $\mathrm{a}$ \\
$31-40$ & $285.000 \pm 86.962$ & $\mathrm{~b}$ & $31-40$ & $231.000 \pm 65802$ & $\mathrm{ab}$ \\
$\leq 30$ & $296.000 \pm 71.972$ & $\mathrm{~b}$ & $\leq 30$ & $249.000 \pm 34168$ & $\mathrm{~b}$ \\
\hline
\end{tabular}

Data tabel 3 menunjukkan interval usia $\leq 30,31-40$, dan 41-50 tahun pada pendonor laki-laki dengan nilai rata-rata $(296.000 \pm 71972,285.000 \pm 86962$ dan $227.000 \pm 51063$ ) menjadi perlakuan yang paling optimal dalam jumlah donor trombositnya sedangkan interval usia $\leq 30$ dan 31-40 pada pendonor perempuan dengan nilai rata-rata $(249.000 \pm 34168$, dan $231.000 \pm 65802$ ) menjadi perlakuan yang paling optimal dalam jumlah donor trombositnya.

\section{SIMPULAN}

Jumlah trombosit pada pendonor laki-laki (245.750 \pm 76300$)$ lebih tinggi daripada jumlah trombosit pada pendonor perempuan $(201.750 \pm 61.564)$. Jumlah trombosit pada pendonor laki-laki menurun seiring dengan bertambahnya usia demikian juga pada pendonor perempuan tapi penurunan terjadi lebih lamban.

\section{DAFTAR PUSTAKA}

Eastham, R.D. \& Slade, R.R. 1992. Clinical Haematology. Seventh edition. Butterwort-Heineman. Ltd. Oxford.

Ganong, W.F. 1987. Fisiologi Kedokteran. Edisi ke-17. Alih Bahasa: M. Djauhari Widjayakusumah. Jakarta: EGC.
Guyton, A.C. 1989. Fisiologi Kedokteran. Jakarta: EGC.

Guyton, A.C. 1995. Human Physiology and Mechanisms of Disease. Edisi ke-3. Alih Bahasa: Petrus Andrianto. Jakarta: EGC.

Kosasih, N.E. 1983. Klinika Capita Selekta Hematologi. Bandung: Alumni.

Kresno, S.B. 1988. Pengantar Hematologi dan Imunohematologi. Fakultas Kedokteran Universitas Indonesia. Jakarta: Gaya Baru.

Linder, C.M. 1992. Biokimia Nutrisi dan Metabolisme. Alih Bahasa: Aminuddin Parakkasi. Jakarta: UI Press.

Marieb, E.N. 2005. Anatomy \& Physiology-second edition. San Fransisco: United State of America.

Rafnar, D. 2001. Development in vitro: Differentiation, Ploidy and Apoptosis. Faculty of MedicineUniversity of Iceland.

Rudy. 2007. Kumpulan Peraturan Perundang-undangan Bidang Kesehatan Transfusi Darah. Jakarta: PMI Pusat.

Rustam, M. 1978. Almanak Transfusi Darah. Jakarta: Pusat Transfusi Darah.

Sadikin, M. 2002. Biokimia Darah. Jakarta: Widya Medika.

Soewolo. 2005. Fisiologi Manusia. Malang: UM Press. 